Finanse, Rynki Finansowe, Ubezpieczenia nr 2/2017 (86)

DOI: $10.18276 /$ frfu.2017.86-06

s. $71-82$

\title{
Three-component portfolios containing gold
}

\begin{abstract}
Katarzyna Mamcarz*
Abstract: Purpose - The goal of the article was to assess the role of gold as a component of three-component portfolios, i.e. gold combined with: the S\&P500 + WILREIT index portfolio, the S\&P500 + TR/J CRB index portfolio, and the WILREIT + TR/J CRB index portfolio.

Design/Methodology/approach - On the basis of the historical data of the analyzed assets, and in accordance with the portfolio theory, two-component minimum variance portfolios and optimal portfolios were constructed, and then, respectively, three-component portfolios containing gold.

Findings - The study has shown that the portfolios with a higher percentage of gold had a lower minimum variance and a higher rate of return. In the optimal portfolios, as the percentage of gold increased, the rate of return dropped with a simultaneous risk reduction, the portfolios with higher gold percentages exhibiting a lower range of the rate of return variability.

Originality/Value - The assessment of the role of gold as a component of investment portfolios is of significant practical importance during the periods of uncertainty in many asset markets.
\end{abstract}

Keywords: diversification, gold portfolio, minimum variance portfolio, optimal portfolio

\section{Introduction}

People investing their capital in gold should be aware of the general situation in the production sector of this metal, which will assist them in forecasting its price. Those who would like to avoid risk will seek to secure themselves against losses in their investment portfolios. One of them is portfolio diversification, ${ }^{1}$ which involves including new classes of assets in the portfolio structure (Stopfer, 2006, p. 131). Gold as a financial instrument can be a crucial component in every investor's portfolio. Many authors (Demidova-Menzel, Heidorn, 2007; Mani, Vuyyuri, 2005; Ghosh, Levin, Macmillan, Wright, 2004; Davidson, Faff, Hillier, 2003; Hillier, Draper, Faff, 2006) in their studies point to the role of gold as an important portfolio diversification instrument due to the negative or slightly positive correlation between its price and a number of classes of assets. Portfolios containing gold are characterised by lower risk and demonstrate a higher rate of return (Chua, Stick, Woodward, 1990; Ciner, 2001).

\footnotetext{
*dr Katarzyna Mamcarz, Uniwersytet Marii Curie-Skłodowskiej w Lublinie, Wydział Ekonomiczny, Zakład Analiz Rynkowych, e-mail: katarzyna.mamcarz@poczta.umcs.lublin.pl

1 The subject matter of portfolio diversification has been known since antiquity. The Greek philosopher Epictetus (50-125) is the author of the popular saying “don't put all your eggs in one basket” (Nauckhoff, 2011, p. 75).
} 
The objective of the article was the assessment of the role of gold as an investment portfolio component. The analysis covered three generated three-component portfolios: minimumvariance portfolios and optimal portfolios. Each portfolio consisted of gold combined with one of three selected two-component portfolios: S\&P500 + the WILREIT portfolio, S\&P500 + the TR/J CRB portfolio and WILREIT + the TR/J CRB portfolio. The quoted stock market index - the S\&P500 index, the TR/J CRB index and the WILREIT index represent the analysed asset classes: shares, commodities and real property. For the objective formulated in such a way, two research hypotheses were formulated: a) combining gold with selected two-component portfolios makes it possible for investors to achieve the diversification effect in the form of an increase of the expected rate of return, with a simultaneous risk reduction and b) optimal portfolios with a higher share of gold are characterised by a lower variation interval of the rate of return.

The analysis covers more than twenty-year-long period (from 1994 to 2015). This is a special period in the evolution of gold prices, which embraces the continuation of stagnation in this market, lasting until April 2001, the unprecedented bull market until early September 2011(on 2 April 2001 the lowest price of gold was recorded at $255.95 \mathrm{USD} / \mathrm{oz}$, and on 6 September 2011 the highest price at $1895.0 \mathrm{USD} / \mathrm{oz}$, an increase by 640.38\%), and apparently the first years of the present decline.

The article consists of an introduction, data sources and methodology (section 1), the basic characteristics of portfolio components (section 2), portfolios containing gold (section 3) and final notes.

\section{Data sources and methodology}

Calculations necessary to evaluate the role of gold as a component in investment portfolios were carried out on the basis of historical daily gold prices according to the London Afternoon (PM) Gold Fix and the values of the S\&P500 stock market index, the TR/J CRB commodity index, the WILREIT real estate index and the rates of return of 20-year US bonds. On the basis of the above-mentioned data, the nominal annual rates of return were calculated for the analysed assets, the basic characteristics of a given class of assets (the expected rate of return and standard deviation), and a correlation coefficients matrix was computed. Also, the average annual rate of return on investment on 20 -year US bonds was calculated as a risk-free rate. Based on the aforementioned data, in accordance with portfolio theory, two-component investment minimum-variance portfolios and optimal portfolios were created, and subsequently three-component minimum-variance portfolios and optimal portfolios containing gold were generated. Optimal portfolios were created using the Sharpe ratio. Calculations were carried out with Solver software. Particular portfolios were presented on a figure presenting the income - risk map. The method was used for each of the analysed portfolios. The summary contains a comparative analysis of the respective portfolios and conclusions. 
The basic characteristics of assets necessary to generate portfolios (the expected rate of return on a portfolio, standard deviation of the rates of return, the Sharpe ratio) were computed with the following formulae:

$$
\begin{gathered}
E\left(R_{p}\right)=\sum_{i=1}^{n} w_{i} E\left(R_{i}\right) \\
\sigma_{p}=\sqrt{\sum_{i=1}^{n} w_{i}^{2} \sigma_{i}^{2}+2 \sum_{i=1}^{n-1} \sum_{j=i+1}^{n} w_{i} w_{j} \sigma_{i} \sigma_{j} \rho_{i j}} \\
S_{p}=\frac{E\left(R_{p}\right)-R_{f}}{\sigma_{p}}
\end{gathered}
$$

where:

$E\left(R_{p}\right)$ - the expected rate of return on a portfolio, $\sigma_{\mathrm{p}}$ - standard deviation of the rate of return on a portfolio, $E\left(R_{i}\right)$ - the expected rate of return on an $i$-th component of a portfolio, $\sigma_{\mathrm{i}}-$ standard deviation of the rate of return of an $i$-th component of a portfolio, $\rho_{\mathrm{ij}}$-correlation coefficient of rates of return of an $i$-th and $j$-th component of a portfolio, $w_{i}$ - the share of an $i$-th component in a portfolio, $w_{j}$ - the share of an $j$-th component in a portfolio, $S_{p}$ - Sharpe ratio, $R_{f}$ - risk-free rate.

For an investor wishing to achieve the highest-expected rate of return with the lowestpossible risk, the so-called effective portfolios are a viable solution. Other portfolios are dominated by this type of portfolio. One of the examples of effective portfolios is the Minimum Variance Portfolio (MVP). The optimal portfolio is characterised by the highest Sharpe ratio. This ratio specifies the amount of the risk premium (measured by a difference between the rate of return on a portfolio and the risk-free rate) per total risk unit (measured by the standard deviation of the rate of return on a portfolio). The expected rate of return and risk for a portfolio depends on the characteristics of each of its components and on the correlation between their rates of return. Investors who are unwilling to take risk, in order to achieve the diversification effect, include in their portfolios the classes of assets which show a negative or low positive correlation with other classes of assets (Markowitz, 1952).

\section{Components of investment portfolios and their characteristics}

The assets analysed in this article include shares, commodities and real estate represented by, respectively, the S\&P500 index, the TRJ/CRB index, the WILREIT index and gold. The S\&P500 index covers the shares of industrial, trade, transport and finance companies. The CRB (Commodity Research Bureau Index) was the earliest commodity-market index, published since 1957. After the respective revisions its name changed to TR/J CRB (The Thomson Reuters/Jefferies CRB Index). The index reflects the changes in the basket of futures contracts of 19 raw materials and commodities divided into four groups. The highest share is represented by petroleum products $(33 \%)$, soft commodities $(21 \%)$, industrial metals $(13 \%)$ 
and cereals (13\%). The WILREIT index (the US Wilshire REIT Index) has been published since 1 January 1978. It reflects changes in shares in Real Estate Investment Trusts (REIT) investing in real estate in a direct or indirect way (buying shares or stocks of companies with real estate among their assets). These directly include investments in real estate (property investments) and investment in real-estate-market financial instruments.

In order to generate the analysed portfolios, the basic characteristics of assets which are their components were computed (Table 1 and Table 2).

\section{Table 1}

The correlation coefficients matrix of annual rates of return

\begin{tabular}{lclll}
\hline & Gold & Index S\&P 500 & Index TRJ/CRB & Index WILREIT \\
\hline Gold & 1 & & & \\
Index S\&P 500 & -0.20 & 1 & & \\
\hline Index TRJ/CRB & 0.53 & 0.21 & 1 & 1 \\
\hline Index WILREIT & 0.09 & 0.41 & 0.37 & \\
\hline
\end{tabular}

Source: the author's own calculations based on Yahoo Finance; YCHARTS; Wilshire Associates; World Gold Council.

The correlation coefficients matrix of rates of return of particular assets shows that they assume relatively low or moderate values. Therefore, these assets can be used to create portfolios for the purpose of achieving the diversification effect.

\section{Table 2}

The characteristics of selected assets in the years 1994-2015

\begin{tabular}{lccc}
\hline Assets & $\begin{array}{c}\text { Expected rates } \\
\text { of return (p.a) }\end{array}$ & $\begin{array}{l}\text { Standard } \\
\text { deviation }\end{array}$ & $\begin{array}{l}\text { Correlation coefficients } \\
\text { with gold }\end{array}$ \\
\hline Gold & $5.80 \%$ & $15.47 \%$ & 1.00 \\
\hline Index S\&P500 & $8.66 \%$ & $18.05 \%$ & -0.20 \\
\hline Index TR/J CRB & $0.14 \%$ & $15.42 \%$ & 0.53 \\
\hline Index WILREIT & $12.88 \%$ & $19.65 \%$ & 0.09 \\
\hline
\end{tabular}

Source: the author's own calculations based on Yahoo Finance; YCHARTS; Wilshire Associates; World Gold Council.

Table 2 shows that particular assets are characterised by different expected rates of return and similar risk levels, measured by the standard deviation of rates of return. Gold has a higher expected rate of return and a slightly higher standard deviation only in comparison with the TR/J CRB index, respectively $5.80 \%$ versus $0.14 \%$ and $15.47 \%$ versus $15.42 \%$. The correlation coefficients between gold and particular classes of assets assume relatively low values, both positive: 0.09 (the WILREIT index) and negative: -0.20 (the S\&P500 index); with the only exception being the moderate value of 0.53 (the TR/J CRB index). Gold can 
therefore be considered by investors as a significant component of their portfolios. The riskfree rate, i.e. the average annual rate of return on investments in 20-year US bonds amounted to $\mathrm{R}_{\mathrm{f}}=4.96 \%$.

\section{Gold as a portfolio component}

\subsection{Portfolio: the S\&P500 index + the WILREIT index + gold}

Portfolio diversification effects through the combination of gold with shares, and real estate, are shown in Table 3 and Figure 1.

\section{Table 3}

The characteristics of investment portfolios: the S\&P500 index, the WILREIT index and gold

\begin{tabular}{lccc}
\hline Portfolios & $\begin{array}{c}\text { Expected rate } \\
\text { of return (p.a) }\end{array}$ & $\begin{array}{c}\text { Standard } \\
\text { deviation }\end{array}$ & Gold share \\
\hline Minimum-variance portfolio (S\&P500+WILREIT) & $10.46 \%$ & $15.75 \%$ & $0.00 \%$ \\
\hline Optimal portfolio (S\&P500+WILREIT) & $12.36 \%$ & $18.26 \%$ & $0.00 \%$ \\
\hline $\begin{array}{l}\text { Minimum-variance portfolio } \\
\text { (S\&P500+WILREIT+gold) }\end{array}$ & $7.58 \%$ & $10.36 \%$ & $52.50 \%$ \\
\hline Optimal portfolio (S\&P500+WILREIT+gold) & $11.74 \%$ & $16.69 \%$ & $8.19 \%$ \\
\hline
\end{tabular}

Source: the author's own calculations based on the sources mentioned for Table 1.

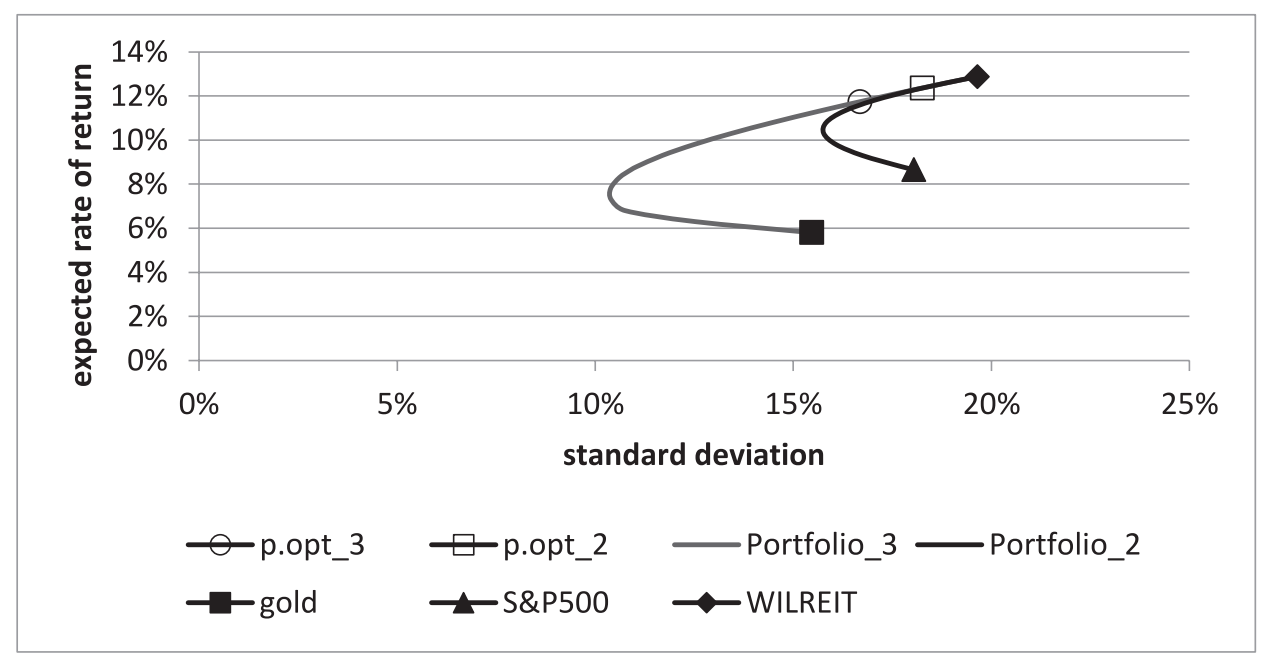

Figure 1. Investment portfolios: the S\&P500 index, the WILREIT index and gold Source: the author's own calculations based on Table 3 . 
The expected rate of return on a two-component minimum-variance portfolio (S\&P500+WILREIT) was $10.46 \%$, with a $15.75 \%$ standard deviation. Including $52.50 \%$ of gold reduced the portfolio's risk to $10.36 \%$, i.e. by as many as 5.39 percentage points. This, however, resulted in a lower drop in the expected rate of return to $7.58 \%$, i.e. 2.88 percentage points. Portfolios with a higher percentage of gold, up to $100 \%$, are ineffective portfolios. An optimum solution is a three-component portfolio with the Sharpe ratio $\left(\mathrm{S}_{\mathrm{p}}=0.406\right)$ and the share of gold amounting to $8.19 \%$. It is a dominant portfolio with a higher rate of return $(11.74 \%)$ and a higher risk $(16.69 \%)$ than the minimum-variance portfolio. Investors who are willing to take risks will include $8.19 \%$ of gold in their portfolios, as they will achieve a higher rate of return (by 4.16 percentage points) than with the minimum-variance portfolio. The three-component optimal portfolio (S\&P500 + WILREIT + gold) is characterised by a lower risk than the two-component optimal portfolio ( $16.69 \%$ versus $18.26 \%$ ), but also by a lower rate of return (11.74\% versus $12.36 \%)$. The portfolio has a considerably lower variation interval in the rate of return than the two-component optimal portfolio $(-4.95 \%$ to $28.43 \%$ versus $-5.90 \%$ to $30.62 \%$ ). To sum up, in the discussed case portfolios containing gold are an alternative for investors who are not willing to take risks.

\subsection{Portfolio: the WILREIT index + the TR/J CRB index + gold}

Portfolio diversification effects through the combination of investments in real estate, commodities and gold are demonstrated in Table 4 and Figure 2.

\section{Table 4}

The characteristics of investment portfolios: the WILREIT index + the TR/J CRB index + gold

\begin{tabular}{lccc}
\hline Portfolios & $\begin{array}{c}\text { Expected rate } \\
\text { of return (p.a) }\end{array}$ & $\begin{array}{c}\text { Standard } \\
\text { deviation }\end{array}$ & $\begin{array}{l}\text { Gold } \\
\text { share }\end{array}$ \\
\hline $\begin{array}{l}\text { Minimum-variance portfolio } \\
\text { (WILREIT+TR/J CRB) }\end{array}$ & $4.12 \%$ & $14.10 \%$ & $0.00 \%$ \\
\hline $\begin{array}{l}\text { Optimal portfolio } \\
\text { (WILREIT+TR/J CRB) }\end{array}$ & $12.88 \%$ & $19.65 \%$ & $0.00 \%$ \\
\hline $\begin{array}{l}\text { Minimum-variance portfolio } \\
\text { (WILREIT+ TR/J CRB+gold) }\end{array}$ & $6.34 \%$ & $12.28 \%$ & $46.28 \%$ \\
\hline $\begin{array}{l}\text { Optimal portfolio } \\
\text { (WILREIT+TR/J CRB+gold) }\end{array}$ & $11.05 \%$ & $15.47 \%$ & $25.83 \%$ \\
\hline
\end{tabular}

Source: the author's own calculations based on the sources mentioned for Table 1. 


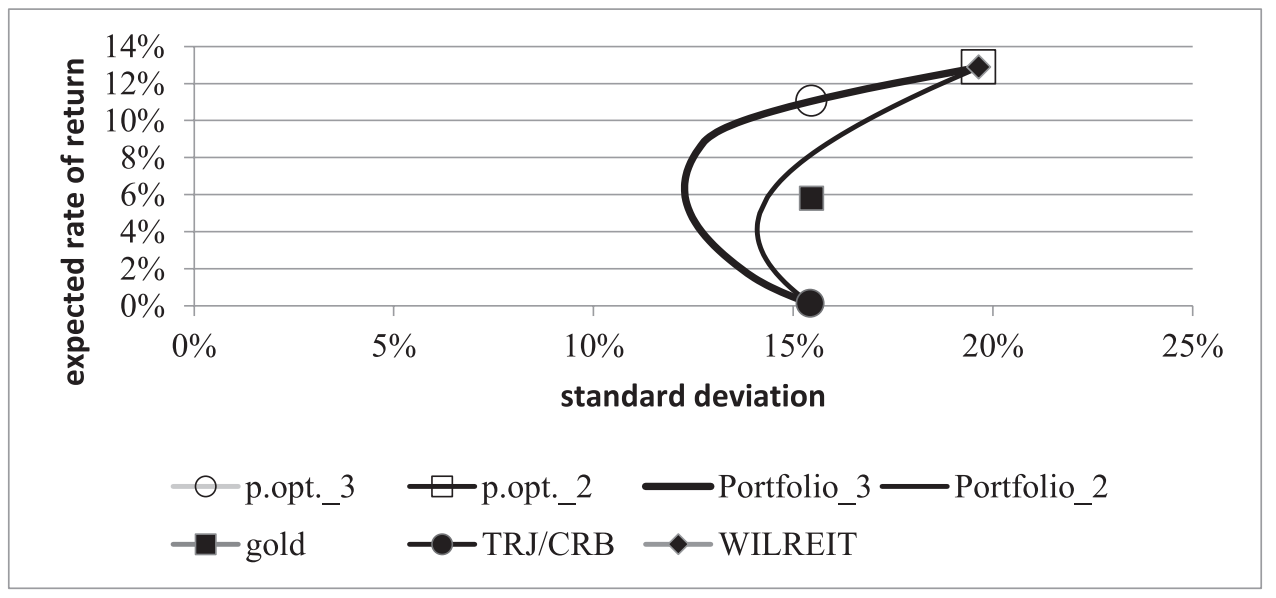

Figure 2. Investment portfolios: the WILREIT index + the TR/J CRB index + gold

Source: the author's own calculations based on Table 4.

The expected rate of return on a two-component minimum-variance portfolio (WILREIT+TR/J CRB) was $4.12 \%$, with a $14.10 \%$ standard deviation. Including $46.28 \%$ of gold resulted in increasing the expected rate of return to $6.34 \%$, i.e. by 2.22 percentage points, with a simultaneous reduction in the portfolio's risk to $12.28 \%$, i.e. by 1.82 percentage points. The diversification effect is clearly seen here. Portfolios with a higher percentage of gold, up to $100 \%$, are ineffective portfolios. An optimum solution is a three-component portfolio with the Sharpe ratio $\left(\mathrm{S}_{\mathrm{p}}=0.396\right)$ and the share of gold amounting to $25.83 \%$. This is a dominant portfolio characterised by a considerably higher rate of return (11.05\%), i.e. by as many as 4.71 percentage points higher, and a slightly higher risk (15.47\%), i.e. by $3.19 \%$ than the minimum-variance portfolio. Investors who are willing to take risks will include $25.83 \%$ of gold in their portfolios, as they will achieve a higher rate of return (by 4.71 percentage points) than for the minimum-variance portfolio. The three-component optimal portfolio (WILREIT + TR/J CRB + gold) is characterised by a considerably lower variation interval of the rate of return than the two-component optimal portfolio $(-4,42 \%$ to $26.52 \%$ versus $-6,77 \%$ to $32,53 \%$ ).

\subsection{Portfolio: S\&P500 + TR/J CRB + gold}

The outcome of portfolio diversification effects through the combination of investments in shares, commodities and gold are demonstrated in Table 5 and Figure 3. 
Table 5

The characteristics of investment portfolios: the S\&P500 index + the TR/J CRB index + gold

\begin{tabular}{lccc}
\hline Portfolios & $\begin{array}{c}\text { Expected rate } \\
\text { of return (p.a) }\end{array}$ & $\begin{array}{c}\text { Standard } \\
\text { deviation }\end{array}$ & $\begin{array}{c}\text { Gold } \\
\text { share }\end{array}$ \\
\hline $\begin{array}{l}\text { Minimum-variance portfolio } \\
\text { (S\&P500+TR/J CRB) }\end{array}$ & $3.56 \%$ & $12.87 \%$ & $0.00 \%$ \\
\hline $\begin{array}{l}\text { Optimal portfolio } \\
\text { (S\&P500+TR/J CRB) }\end{array}$ & $8.66 \%$ & $18.05 \%$ & $0.00 \%$ \\
\hline $\begin{array}{l}\text { Minimum-variance portfolio } \\
\text { (S\&P500+TR/J CRB+gold) }\end{array}$ & $6.41 \%$ & $10.45 \%$ & $50.02 \%$ \\
\hline $\begin{array}{l}\text { Optimal portfolio } \\
\text { (S\&P500+TR/J CRB+gold) }\end{array}$ & $7.68 \%$ & $12.02 \%$ & $34.01 \%$ \\
\hline
\end{tabular}

Source: the author's own calculations based on the sources mentioned for Table 1.

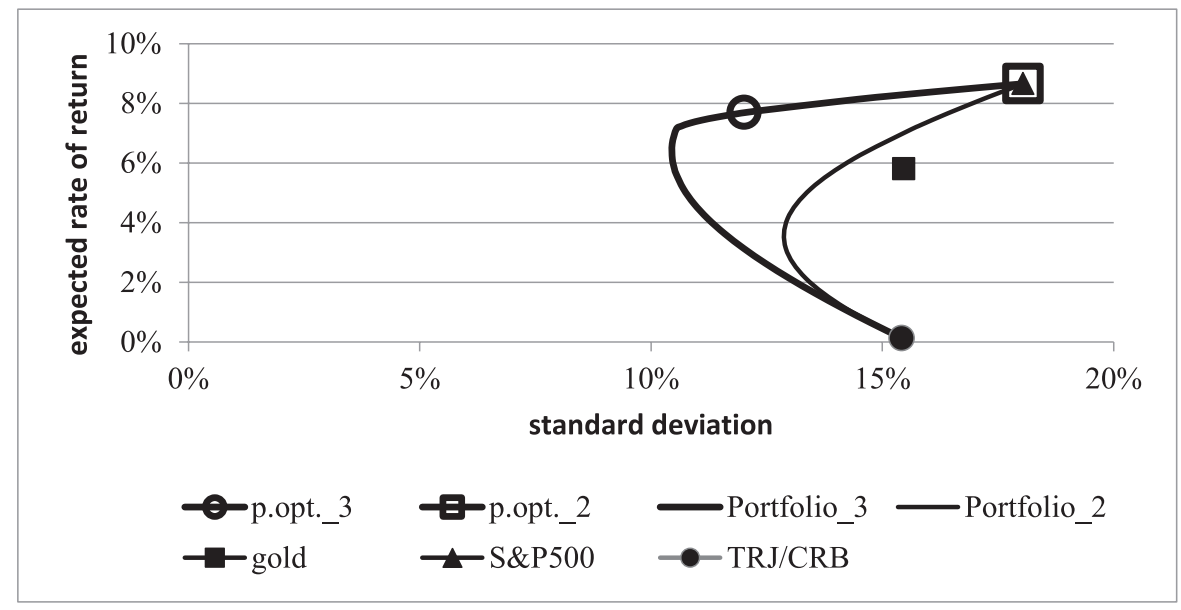

Figure 3. Investment portfolios: the S\&P500 index + the TR/J CRB index + gold Source: the author's own calculations based on Table 5.

The expected rate of return on a two-component minimum-variance portfolio (S\&P500+TR/J CRB) was $3.56 \%$, with a $12.87 \%$ standard deviation. Including $50.02 \%$ of gold resulted in increasing the expected rate of return to $6.41 \%$, i.e. by 2.85 percentage points, with a simultaneous reduction in the portfolio's risk to $10.45 \%$, i.e. by 1.82 percentage points. In this case the diversification effect is obvious. Portfolios with a higher percentage of gold, up to $100 \%$, are ineffective portfolios. An optimum solution is a three-component portfolio with the Sharpe ratio $\left(\mathrm{S}_{\mathrm{p}}=0.227\right)$ and the share of gold amounting to $34.01 \%$. This is a dominant portfolio characterised by a considerably higher rate of return $(7.68 \%)$, i.e. by 1.27 percentage points higher, and a slightly higher risk (12.02\%), i.e. by 1.57 percentage points more than the minimum-variance portfolio. Investors who are willing to take risks 
will include $34.01 \%$ of gold in their portfolios, as they will achieve a higher rate of return (by 1.27 percentage points) than for the minimum-variance portfolio. The three-component optimal portfolio (S\&P500+TR/J CRB + gold) is characterised by a considerably lower variation interval of the rate of return than the two-component optimal portfolio $(-4.34 \%$ to $19.70 \%$ versus $-9.39 \%$ to $26.71 \%$ ).

\section{Concluding remarks}

The article contains an evaluation of the role of gold as a component in the three generated three-component portfolios. Gold, with an annual rate of return of 5.80\% and relatively low correlation coefficients with other classes of assets, constitutes a substantial component in the investment portfolio. Each portfolio contained gold in combination with a two-component portfolio The above analysis shows that the expected rate of return and the risk related to particular portfolios were determined by the level of the basic characteristics of their components. By compiling their basic characteristics it is possible to create rankings of the portfolios: minimum-variance portfolios (Table 6) and optimal portfolios (Table 7 and Figure 4).

Three-component portfolios with the lowest minimum variance, ordered by increasing risk: S\&P500 + WILREIT + gold $(\sigma=10.36 \%)$, S\&P500 + TR/J CRB + gold ( $\sigma=10.45 \%)$, WILREIT + TR/J CRB + gold $(\sigma=12.28 \%)$. They include various proportions of gold, from $46.28 \%$ (WILREIT + TR/J CRB + gold) to 52.50\% (S\&P500+WILREIT+gold). The higher the gold percentage, the lower the minimum variance and the higher rate of return. Portfolios with a higher percentage of gold are characterised by the lowest minimum variance and, simultaneously, a higher rate of return. The diversification effect in the form of an increased expected rate of return, with a simultaneous reduction in the risk level as compared to twocomponent portfolios, will be achieved by investors only after including gold in their two portfolios: the WILREIT + TR/J CRB portfolio and the S\&P500 + TR/J CRB portfolio. In this respect, the first research hypothesis was found to be true. In the case of the S\&P500+ WILREIT portfolio, the decrease in the risk rate was associated with a lower expected rate of return. Investors unwilling to take risks will also include gold in this portfolio.

Table 6

Three-component minimum-variance investment portfolios containing gold

\begin{tabular}{llll}
\hline Portfolios & $\begin{array}{l}\text { Expected rate } \\
\text { of return (p.a) }\end{array}$ & $\begin{array}{l}\text { Standard } \\
\text { deviation }\end{array}$ & $\begin{array}{l}\text { Gold } \\
\text { share }\end{array}$ \\
\hline Portfolio: S\&P500+WILREIT+gold & $7.58 \%$ & $10.36 \%$ & $52.50 \%$ \\
\hline Portfolio: S\&P500+TR/J CRB +gold & $6.41 \%$ & $10.45 \%$ & $50.02 \%$ \\
\hline Portolio: WILREIT+TR/J CRB+gold & $6.34 \%$ & $12.28 \%$ & $46.28 \%$ \\
\hline
\end{tabular}

Source: the author's own calculations based on Tables 3, 4, 5 . 
Table 7

Three-component optimal investment portfolios containing gold

\begin{tabular}{llllc}
\hline Portfolios & $\begin{array}{l}\text { Expected rate } \\
\text { of return (p.a) }\end{array}$ & $\begin{array}{l}\text { Standard } \\
\text { deviation }\end{array}$ & $\begin{array}{l}\text { Sharpe } \\
\text { Ratio }\end{array}$ & $\begin{array}{l}\text { Gold } \\
\text { share }\end{array}$ \\
\hline Portfel: S\&P500+WILREIT+gold & $11.74 \%$ & $16.69 \%$ & 0.406 & $8.19 \%$ \\
\hline Portfel: WILREIT+TR/J CRB+gold & $11.05 \%$ & $15.47 \%$ & 0.394 & $25.83 \%$ \\
\hline Portfel: S\&P500+TR/J CRB+gold & $7.68 \%$ & $12.02 \%$ & 0.227 & $34.01 \%$ \\
\hline
\end{tabular}

Source: the author's own calculations based on Tables 3, 4, 5 .

As regards the most favourable correlation between the risk premium and the total risk expressed by the Sharpe ratio, the optimal portfolios can be ranked as follows: S\&P500 + WILREIT + gold $\left(\mathrm{S}_{\mathrm{p}}=0.406\right)$, WILREIT + TR/J CRB + gold $\left(\mathrm{S}_{\mathrm{p}}=0.394\right), \mathrm{S} \& \mathrm{P5} 50+\mathrm{TR} / \mathrm{J}$ $\mathrm{CRB}+$ gold $\left(\mathrm{S}_{\mathrm{p}}=0.227\right)$. They are also presented in Figure 4. The straight lines linking the points illustrating the respective optimal portfolios with the point corresponding to the riskfree rate $(4.96 \%)$ on the ordinate axis form, with the parallel axis of abscissas running from this point, angles with an inclination from the highest to the lowest in the aforementioned order of portfolios. The size of the angle shows the value of the risk premium. The percentage of gold in the portfolios varies. The portfolios can be ordered as follows, starting from the highest gold percentage: S\&P500 + TR/J CRB + gold (34.01\%), WILREIT + TR/J CRB + gold $(25.83 \%)$, S\&P500 + WILREIT + gold $(8.19 \%)$. Together with the increase in the percentage of gold, the expected rate of return drops, together with a simultaneous decrease in the investment risk. With regard to the extensive variation interval of the rate of return, optimal portfolios were ranked as follows, starting from the broadest: S\&P500 + WILREIT + gold $(-4.95 \%$ to $28.43 \%)$, WILREIT + TR/J CRB + gold $(-4.42 \%$ to $26.52 \%)$, (S\&P500 + $\mathrm{TR} / \mathrm{J} \mathrm{CRB}+$ gold) $(-4.34 \%$ to $19.70 \%)$, i.e. a reversed ranking in relation to the percentage of the gold component. To put it differently, optimal portfolios with a higher share of gold are characterised by a lower variation interval of the rate of return. Therefore, the second research hypothesis was found to be true. Investors willing to take more risks will prefer optimal portfolios with the highest variation interval of the rate of return. To recapitulate, investors who create portfolios containing gold will take into consideration the purpose of the investment and their attitude to risk-taking. When evaluating and, possibly, applying the results in practice, investors should take into account the fact that the analysis covered a specific, over-20-year period of the gold market development, in which an unprecedented 10 -year rise was followed by a substantial decrease in gold prices. 


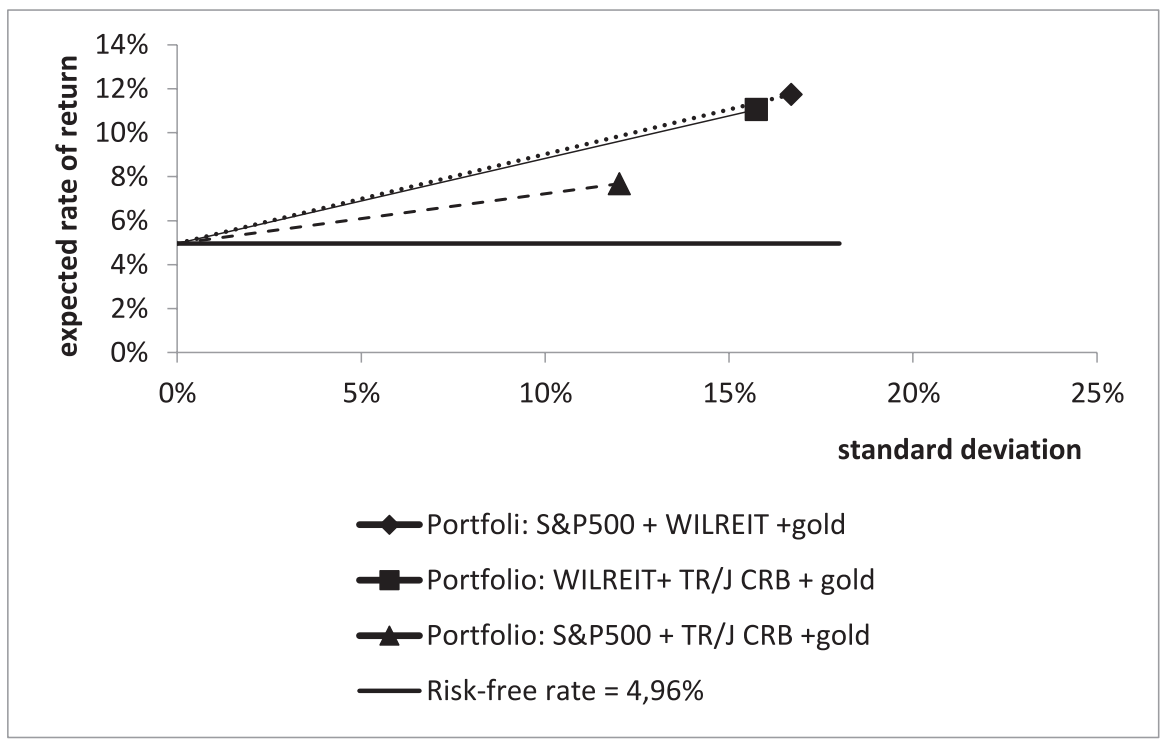

Figure 4. Three-component optimal investment portfolios containing gold Source: the author's own calculations based on Table 7.

\section{References}

Chua, J., Stick, G., Woodward, R. (1990). Diversifying with Gold Stocks. Financial Analysts Journal, 46 (4), $76-79$.

Ciner, C. (2001). On the Longrun Relationship between Gold and Silver: A Note. Global Finance Journal, 12, 299-303.

Davidson, S., Faff, R., Hillier, D. (2003). Gold factor exposures in international asset pricing. Journal of International Financial Markets, Institutions and Money, 13 (3), 271-289.

Demidova-Menzel, N., Heidorn, T. (2007). Gold in the Investment Portfolio. Frankfurt School-Working Paper, $87,3-45$.

Ghosh, D., Levin, J., Macmillan, P., Wright, E. (2004). Gold as an inflation hedge? Studies Economics and Finance, $22(1), 1-25$.

Hillier, D., Draper, P., Faff, R. (2006). Do Precious Metals Shine? An Investment Perspective. Financial Analysts Journal, 62 (2), 98-106.

Mani, G., Vuyyuri, S. (2005). Gold Pricing in India: An Econometric Analysis. Journal of Economic Research, 16 (1). Retrived from: http://ssrn.com/abstract $=715841$.

Markowitz, H. (1952). Portfolio selection. The Journal of Finance, 7 (1), 77-91.

Nauckhoff, M. (2011). Strategische Metalle und seltene Erden, 2. Auflage. München: FinanzBuch Verlag.

Stopfer, A. (2006). Rohstoffe zur nominalen und realen Porfolio-Absicherung. In: U. Bergold, R. Eller (eds.), Investmentstrategien mit Rohstoffen (pp. 131-154). Weinheim: Wiley-VCH Verlag. 


\title{
Internet sites
}

Yahoo Finance: http://finance.yahoo.com

YCHARTS: http://ycharts.com

Wilshire Associates: http://www.wilshire.com

World Gold Council: http://www.gold.org

\section{TRZYSKŁADNIKOWE PORTFELE INWESTYCYJNE Z KOMPONENTEM ZLOTA}

\begin{abstract}
Abstrakt: Cel - Celem artykułu była ocena roli złota jako komponentu trzech portfeli trzyskładnikowych. Każdy zawierał złoto połączone z portfelem dwuskładnikowym: portfelem S\&P500 + WILREIT, portfelem S\&P500 + TR/J CRB i portfelem WILREIT + TR/J CRB.

Metodologia badania - Na podstawie historycznych danych analizowanych aktywów, zgodnie z teorią portfela, zostały skonstruowane dwuskładnikowe portfele o minimalnej wariancji i portfele optymalne, a następnie odpowiednio portfele trzyskładnikowe zawierające inwestycje w złoto.

Wynik - Analiza wykazała, że oczekiwana stopa zwrotu i ryzyko portfeli determinowane były przez poziom charakterystyk ich komponentów. Portfele o większym udziale złota miały niższą minimalną wariancję i wyższą stopę zwrotu. W portfelach optymalnych wraz ze wzrostem odsetka złota spadała stopa zwrotu przy jednoczesnym zmniejszeniu ryzyka inwestycji, przy czym portfele o wyższym udziale złota wykazały niższy przedział zmienności stopy zwrotu. Analiza obejmowała lata 1994-2015.

Oryginalność/Wartość - Oryginalność badań polega na ocenie roli złota jako komponentu portfeli inwestycyjnych w okresach niepewności na wielu rynkach aktywów.
\end{abstract}

Słowa kluczowe: dywersyfikacja, portfel z komponentem złota, portfel o minimalnej wariancji, portfel optymalny

\section{Cytowanie}

Mamcarz, K. (2017). Three-component portfolios containing gold. Finanse, Rynki Finansowe, Ubezpieczenia, 2 (86), 71-82. DOI: $10.18276 /$ frfu.2017.86-06. 